\title{
Understanding Generation Y' Perceptions and Purchase Intentions Related to Green Practice in Foodservice Operations
}

\author{
Theodosia C. Nathalia \\ Hospitality Management \\ Pelita Harapan School of Hospitality and Tourism \\ Banten, Indonesia \\ theodosia.nathalia@uph.edu
}

\author{
Yustisia Kristiana \\ Travel Industry Management \\ Pelita Harapan School of Hospitality and Tourism \\ Banten, Indonesia \\ yustisia.kristiana@uph.edu
}

\begin{abstract}
Purpose - The use of green practices in the foodservice industry has become an interest area in in the world of travel, tourism, and hospitality. Many foodservice operators have accepted the importance of promoting environmental awareness to create competitive advantages. The foodservice industry is one of the biggest consumers of energy. The paper aims to examine generation $\mathrm{Y}^{\prime}$ perceptions, sustainability and purchase intentions on green practice in order to help determine strategies regarding the future management of green initiatives.

Design/methodology/approach - The study used a convenience sample of consumers of the restaurant. The survey asked respondents to indicate their level of agreement to a variety of statements about the use of green practices, sustainability and purchase intentions in the foodservice industry. The survey also asked respondents to indicate their demographic profile. Respondents are generation Y who were born 1981-2000. The data were analyzed by using SPSS.

Findings - The results revealed that generation Y believed that they have the knowledges about green practices and sustainability but they would still like to know more about it. They also expressed preferences related to restaurants that are environmentally friendly and use environmentally safe products.

Originality/value - This study found that gender influenced generation $Y^{\prime}$ perceptions about purchase intentions to the green restaurants.
\end{abstract}

Keywords Sustainability, Green Practices, Consumer Perception, Purchase Intentions

\section{INTRODUCTION}

Foodservice industry is one of the important components in the tourism product and currently many of them apply the green practices. The use of green practices in the foodservice industry has become an interest area in in the world of travel, tourism, and hospitality. Many foodservice operators have accepted the importance of promoting environmental awareness to create competitive advantages. Hospitality businesses could negatively influence the sustainability of the local environments in which they operate through their overconsumption of natural resources. The foodservice industry is one of the biggest consumers of energy. According to the Energy Information Administration, restaurants use almost three times the energy of the average commercial building per square foot. In addition, restaurants utilize an immense amount of water and other nonrenewable resources like natural gas and petroleum. Those businesses which have recognized the issue and started to implement changes in their everyday operations are commonly called "green" or "sustainable" businesses [2].

Green practices refer to actions that protect the environment and/or products made with little environmental harm because they are produced in an environmentally and ecologically friendly way $[3,4]$. As a way of assuming their environmental responsibility, the restaurants are expected to be subjected to green trends. As an important issue, we cannot ignore the consumers' growing understanding of the effect of food consumption on health [5], together with increasing environmental awareness throughout society, which has resulted in a growing trend of green restaurants.

Each generation has unique expectations, experiences, generational history, lifestyles, values, and demographics that influence their buying behaviors. In Indonesia, generation Y is the biggest population. Table 1 below shows population of generation $\mathrm{Y}$ in Indonesia:

TABEL I. POPULATION OF GENERATION Y IN INDONESIA, 2015

\begin{tabular}{cr}
\hline Age Group & \multicolumn{1}{c}{ Population } \\
\hline $15-19$ & 22.107 .723 \\
\hline $20-24$ & 21.467 .771 \\
\hline $25-29$ & 20.830304 \\
\hline $30-34$ & 20.459 .299 \\
\hline $35-39$ & 19.838 .306 \\
\hline Total & 104.703 .403 \\
\hline
\end{tabular}

Source: Statistics Indonesia (2016)

Generation $\mathrm{Y}$ have better spending power and are savvy consumers. In the foodservice industry, generation $\mathrm{Y}$ is the key market segment due to their eating habits, lifestyle and also adventurous in trying new food [6]. The paper aims to examine generation $\mathrm{Y}^{\prime}$ perceptions, sustainability and purchase intentions on green practice in order to help determine strategies regarding the future management of green initiatives. 


\section{LITERATURE REVIEW}

\section{Generation $Y$}

Generation Y also known as Millennials, are people born between 1980 and 1995 or and 2000 according to another group of scientists [7]. Generation Ys are civic-minded and socially conscious individuals [8], and consumers who want quality goods, brand loyal, and willing to pay more for brand names [9]. Generation $\mathrm{Y}$ is important for marketers because of the impact that they have on their families' purchase decisions [10]. A previous study focusing on generation Y consumers' found that the majority $(77 \%)$ of generation $\mathrm{Y}$ claimed that they care about the environment. Generation $\mathrm{Y}$ will favor companies that show a demonstrated commitment to sustainability and social improvement [11].

\section{Green Practice in Foodservice Industry}

Green restaurant is a restaurant with new or renovated structures designed, constructed, operated, and demolished in an environmentally-friendly and energy-efficient manner [12]. GRA [13], a national non-profit organization that promotes "Creating an environment Sustainable Restaurant Industry" provides a convenient and cost-effective way for restaurants, manufacturers, distributors, and consumers to become more environmentally responsible. These suggest green initiatives in the following areas:

- Water efficiency;

- Waste reduction and recycling;

- Sustainable furnishing and building materials;

- Sustainable food: restaurants purchase sustainable organic and local family farms;

- Energy: using more energy-efficient equipment, offsetting energy usage, and generating on-site renewable clean sources of energy;

- Disposables: restaurants should use products that are made from bio-based materials, or materials that have been previously recycled and made into these new products;

- Chemical and pollution reduction.

Recent studies founded that when restaurants are faced with environmental innovations, they will place great emphasis on economic and positive benefits that are associated with observable resource savings [14]. Environmental practices in the service industry are positively related to performance through the mediating effect of enhanced consumer satisfaction and loyalty [15]. In other words, restaurants could cater to the relatively new interest for eco-friendly practices by consumers with the consequence of increasing consumer satisfaction and loyalty. The latter one will then ultimately lead to increased performance in the market, hence a sustainable advantage over competitors. With these results in mind it should be only a logic consequence for restaurant owners and managers to engage in green practices.

\section{Sustainability}

Relevant studies have shown that consumers had experienced a green restaurant, and nearly 40 per cent of them had dined at the environmentally friendly restaurant at least once a month, most of them had difficulty with defining a green restaurant [16]. Substantial proportion of consumers participating in the researches appeared to be aware of ecofriendly foods and purchase the foods, although they perceived price as a barrier [17, 18].

A 2010 study on consumer perception of green restaurants suggests that restaurants' green practices are often unnoticed by the consumer because they are happening in the back-of-the-house and consequently do not provide the same level of engagement as other industries. Consumers of the globally branded restaurant do appreciate the use of local products [19]. Although not purely consumer-focused, a study of manager attitudes towards green practices in restaurant industry, concluded that engaging in green practices can lead to strengthened consumer relations and increased harmony with the community [20].

\section{Purchase Intention}

Intention is subjective judgments about how a person will behave in future and it is usually serves as dependent variable in many service research and satisfaction models [21, 22]. Consumers that received an excellent and memorable experience from the restaurant will form a favorable behavioral intention such as recommending the restaurant to others, spread positive word of mouth or become a loyal consumer will ultimately lead to revisit intention [21, 23]. The relationships among knowledge of green practices, personal green behavior, the willingness to buy green products or use green businesses and in some cases pay a premium price for those products has been well documented in the literature [1, $24,25,26]$.

Consumers' concern for the environment has been shown to be a good predictor for having positive purchase intentions for green products or products from companies employing green practices. There is a positive, significant relationship between a consumer's ecological behavior and their intention to patronize a green restaurant $[1,27]$. 
TABLE II. Personal and LifESTyle Characteristics By GeNERATION

\begin{tabular}{|l|l|l|l|l|}
\hline & $\begin{array}{c}\text { Veterans } \\
\mathbf{( 1 9 2 2 - 1 9 4 5 )}\end{array}$ & $\begin{array}{c}\text { Baby Boomers } \\
\mathbf{( 1 9 4 6 - 1 9 6 4 )}\end{array}$ & \multicolumn{1}{|c|}{$\begin{array}{c}\text { Generation X } \\
(\mathbf{1 9 6 5 - 1 9 8 0 )}\end{array}$} & $\begin{array}{l}\text { Generation Y } \\
\mathbf{( 1 9 8 1 - 2 0 0 0 )}\end{array}$ \\
\hline Core Value & $\begin{array}{l}\text { Respect for } \\
\text { authority } \\
\text { Conformers } \\
\text { Discipline }\end{array}$ & $\begin{array}{l}\text { Optimism } \\
\text { Involvement }\end{array}$ & $\begin{array}{l}\text { Skepticism } \\
\text { Fun } \\
\text { Informality }\end{array}$ & $\begin{array}{l}\text { Realism } \\
\text { Confident } \\
\text { Extreme fun } \\
\text { Social }\end{array}$ \\
\hline Family & $\begin{array}{l}\text { Traditional } \\
\text { Nuclear }\end{array}$ & Disintegrating & Latch-key kids & Merged families \\
\hline Education & A dream & A birth right & A way to get there & $\begin{array}{l}\text { An incredible } \\
\text { expense }\end{array}$ \\
\hline $\begin{array}{l}\text { Communication } \\
\text { Media }\end{array}$ & $\begin{array}{l}\text { Rotary phones } \\
\text { One-on-one } \\
\text { Write a memo }\end{array}$ & $\begin{array}{l}\text { Touch-tone phones } \\
\text { Call me anytime }\end{array}$ & $\begin{array}{l}\text { Cell phones } \\
\text { Call me only at } \\
\text { work }\end{array}$ & $\begin{array}{l}\text { Internet } \\
\text { Picture phones } \\
\text { E-mail }\end{array}$ \\
\hline $\begin{array}{l}\text { Dealing with } \\
\text { Money }\end{array}$ & $\begin{array}{l}\text { Put it away } \\
\text { Pay cash }\end{array}$ & Buy now, pay later & $\begin{array}{l}\text { Cautious } \\
\text { Conservative Save, save, save }\end{array}$ & Earn to spend \\
\hline
\end{tabular}

Source: Fairleigh Dickinson University Magazine (2005)

Based on the literature review, the conceptual model proposed is:

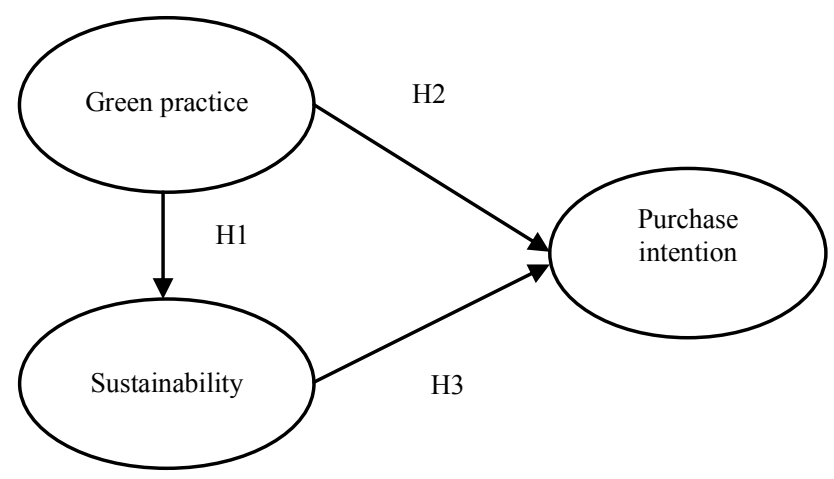

FIGURE I. STRUCTURAL MODEL

The proposed hypotheses are:

H1 : The green practice has a positive impact on sustainability

$\mathrm{H} 2$ : The green practice has a positive impact on purchase intention

H3 : The sustainability has a positive impact on purchase intention

\section{Methodology}

The study used a convenience sample of consumers of the restaurant. The population in this study was generation $\mathrm{Y}$, who were born 1981-2000. The data collected data through a structured questionnaire based on the review of relevant literatures and an overview of the theories. Indicators were used to explain the construct in research model by using Likert
Scale $1-6$. Respondents were asked to answer the questions in the questionnaire regarding the green practice, sustainability and purchase intention. Each variable is operationalized in order to do the statistical analyses. The sources of each adapted indicators are presented in Table 3 .

TABLE III. VARIABLES AND OPERATIONAL INDICATORS

\begin{tabular}{|c|c|}
\hline Variables & $\begin{array}{ll}\text { Indicators } \\
\end{array}$ \\
\hline $\begin{array}{l}\text { Green Practice } \\
{[28]}\end{array}$ & $\begin{array}{l}\text { 1. Utilizing recycling throughout the restaurant } \\
\text { 2. Not using Styrofoam to-go cups and } \\
\text { 3. } \\
\text { 3. Serviners } \\
\text { 4. Using energanic food and drinks } \\
\text { 5. Recycled wood furniture } \\
\text { 6. Recycled paper products } \\
\text { 7. Organic cotton staff uniforms } \\
\text { 8. Purchasing local foods } \\
\text { 9. Composting as a means of waste disposal } \\
\text { 10. Low-flow toilets in the restroom } \\
\text { 11. Utilizing non-toxic cleaners } \\
\text { 12. Motion sensors for lights } \\
\text { 13. Offering filtered tap water } \\
\text { 14. Automatically operated faucets }\end{array}$ \\
\hline $\begin{array}{l}\text { Sustainability } \\
\text { [29] }\end{array}$ & $\begin{array}{l}\text { 1. Sustainability is equivalent to being green or } \\
\text { eco-friendly } \\
\text { 2. Sustainability is beyond being green or eco- } \\
\text { friendly } \\
\text { 3. Embedding green in foodservice operation } \\
\text { 4. Sustainability is initiative that helps } \\
\text { foodservice operation implement } \\
\text { conservation practice }\end{array}$ \\
\hline $\begin{array}{l}\text { Purchase } \\
\text { Intention [30] }\end{array}$ & $\begin{array}{ll}\text { 1. } & \text { Food quality } \\
\text { 2. } & \text { Service quality } \\
\text { 3. } & \text { Price } \\
\text { 4. } & \text { Location } \\
\text { 5. } & \text { Local products are used in meal preparation } \\
\text { 6. } & \text { Restaurant architecture and ambiance } \\
\text { 7. } & \text { Environmental record } \\
\text { 8. } & \text { Nutritious food } \\
\text { 9. } & \text { Existence of recycling bins for consumer or } \\
& \text { employee use } \\
\text { 10. } & \text { Types of service }\end{array}$ \\
\hline
\end{tabular}




\section{FINDINGS AND DISCUSSION}

\section{Respondent Profile}

In this study, the respondents were divided in socioeconomic profile including gender, age, marital status, education level and occupation as illustrated in table below. Female respondents represent 69 percent $(n=121)$ while the male is 31 percent $(n=67)$ respondents of this study. Table 4 shows most of the respondents age falls between 16-19 years old which amounts to 52 percent $(n=91)$. Meanwhile, 34 percent $(n=59)$ of the respondents age falls between 20-24 years old, 10 percent $(n=18)$ respondents are age between 25 30 years old, and 4 percent $(n=7)$ respondents are more than 30 years old. Based on the figure, it shows that majority generation $\mathrm{Y}$ that has been involved in this study are among those who age 16-19 years old. Most of them are the university students and the respondents of this study were achieved as it is focusing on generation Y. Table shows that 86 percent $(n=150)$ respondents are single and 24 percent $(n=25)$ are married. As shown in Table 4 also shows that the majority of respondents are from high school with 61 percent $(n=106)$, respondents whilst bachelor degree 32 percent $(n=56)$ respondent. Certificate/diploma holder 6 percent $(n=10)$ respondents, and 1 percent $(n=3)$ respondents hold master degree. The majority of respondents are student with 54 percent $(n=95)$, employed for wages 23 percent $(n=40)$, self-employed 22 percent $(n=38)$ and other 1 percent $(n=2)$.

TABLE IV. RESPONDENT PROFILE

\begin{tabular}{lcc}
\hline \multicolumn{1}{c}{ Description } & Frequency & Percent \\
\hline Gender & 67 & 31 \\
Male & 121 & 69 \\
Female & & \\
\hline Age & 91 & 52 \\
16-19 year & 59 & 34 \\
20 -24 year & 18 & 10 \\
25-30 year & 7 & 4 \\
More than 30 year & & \\
\hline Marital Status & 150 & 86 \\
Single & 25 & 24 \\
Married & 106 & 61 \\
\hline Educational Level & 10 & 6 \\
High School & 56 & 32 \\
Certificate/Diploma & 3 & 1 \\
Bachelor Degree & & \\
Master Degree & 40 & 23 \\
\hline Occupation & 38 & 22 \\
Employed for wages & 95 & 54 \\
Self-employed & 2 & 1 \\
Student & & \\
Other & &
\end{tabular}

\section{Reliability Analysis}

Reliability test was performed to measure the internal consistency of the scale used in this study. The minimum value requirement of Cronbach Alpha is 0.70 [31]. Table 5 shows the Cronbach Alpha values of the study variables, ranging from 0.90 to 0.98 , all of which exceeds the recommended level of 0.70 .
TABLE V. RELIABILITY ANALYSIS

\begin{tabular}{lcc}
\hline \multicolumn{1}{c}{ Variables } & n & Cronbach Alpha \\
\hline Green practice & 14 & 0.98 \\
\hline Sustainability & 4 & 0.90 \\
\hline Purchase intention & 10 & 0.95 \\
\hline
\end{tabular}

\section{Descriptive Statistics}

Table 6 provides a summary of the descriptive statistics for green practice in foodservice industry (GP), sustainability (S) and purchase intention (PI). As regards the measure of central tendency (mean values) of these factors, it appears that most of these values cluster around point four (somewhat agree) on the instrument scale and low standard deviation value (below 1.00). It is indicating that most of the respondents have a positive perception and relatively consistent regarding the green practice in foodservice industry, sustainability and purchase intention.

TABLE VI. A SuMMARY OF DESCRIPTIVE STATISTICS

\begin{tabular}{|c|c|c|c|c|c|}
\hline & $\mathbf{N}$ & Min. & Max. & Mean & $\begin{array}{c}\text { Std. } \\
\text { Deviation }\end{array}$ \\
\hline GP1 & 175 & 1 & 6 & 4.41 & 0.954 \\
\hline GP2 & 175 & 2 & 6 & 4.33 & 0.948 \\
\hline GP3 & 175 & 2 & 6 & 4.35 & 0.965 \\
\hline GP4 & 175 & 2 & 6 & 4.35 & 0.958 \\
\hline GP5 & 175 & 2 & 6 & 4.33 & 0.917 \\
\hline GP6 & 175 & 1 & 6 & 4.38 & 0.962 \\
\hline GP7 & 175 & 1 & 6 & 4.40 & 0.994 \\
\hline GP8 & 175 & 2 & 6 & 4.37 & 0.967 \\
\hline GP9 & 175 & 1 & 6 & 4.42 & 0.985 \\
\hline GP10 & 175 & 2 & 6 & 4.41 & 0.898 \\
\hline GP11 & 175 & 2 & 6 & 4.36 & 0.923 \\
\hline GP12 & 175 & 2 & 6 & 4.38 & 0.975 \\
\hline GP13 & 175 & 2 & 6 & 4.38 & 0.908 \\
\hline GP14 & 175 & 2 & 6 & 4.37 & 0.931 \\
\hline $\mathrm{S} 1$ & 175 & 2 & 6 & 4.38 & 0.975 \\
\hline $\mathrm{S} 2$ & 175 & 3 & 6 & 4.56 & 0.855 \\
\hline S3 & 175 & 1 & 6 & 4.42 & 0.985 \\
\hline S4 & 175 & 2 & 6 & 4.41 & 0.898 \\
\hline PI1 & 175 & 3 & 6 & 4.86 & 0.931 \\
\hline PI2 & 175 & 3 & 6 & 4.87 & 0.932 \\
\hline PI3 & 175 & 3 & 6 & 4.56 & 0.855 \\
\hline PI4 & 175 & 3 & 6 & 4.54 & 0.927 \\
\hline PI5 & 175 & 3 & 6 & 4.76 & 0.909 \\
\hline PI6 & 175 & 3 & 6 & 4.84 & 0.883 \\
\hline PI7 & 175 & 3 & 6 & 4.76 & 0.909 \\
\hline PI8 & 175 & 3 & 6 & 4.60 & 0.851 \\
\hline PI9 & 175 & 3 & 6 & 4.64 & 0.796 \\
\hline PI10 & 175 & 3 & 6 & 4.60 & 0.851 \\
\hline $\begin{array}{l}\text { Valid N } \\
\text { (listwise) }\end{array}$ & 175 & & & & \\
\hline
\end{tabular}

\section{Regression Analysis}

The output for green practice as independent variable and sustainability as dependent variable (H1) shows the calculation of adjusted R square of 0.918 , meaning $91.8 \%$ variable of green practice can be explained by the variable of sustainability, while the rest $(8.2 \%)$ is explained by other variables. The output for green practice as independent variable and purchase intention as dependent variable (H2) shows the calculation of adjusted $\mathrm{R}$ square of 0.669 , meaning $66.9 \%$ variable of green practice can be explained by the variable of 
purchase intention, while the rest (33.1\%) is explained by other variables. The output for sustainability as independent variable and purchase intention as dependent variable (H3) shows the calculation of adjusted $\mathrm{R}$ square of 0.613 , meaning $61.3 \%$ variable of sustainability can be explained by the variable of purchase intention, while the rest $(38.7 \%)$ is explained by other variables.

$\mathrm{F}$ value for green practice as independent variable and sustainability as dependent variable (H1) equal to 1936.663 with a significant level of 0,000 is smaller than 0.005 , the regression model can be used to predict green practice and sustainability. F value for green practice as independent variable and purchase intention as dependent variable (H2) equal to 276.419 with a significant level of 0,000 is smaller than 0.005 , the regression model can be used to predict green practice and purchase intention. $F$ value for sustainability as independent variable and purchase intention as dependent variable (H3) equal to 142.791 with a significant level of 0,000 is smaller than 0.005, the regression model can be used to predict sustainability and purchase intention.

TABEL VII. REGRESSION ANALYSIS

\begin{tabular}{clccc}
\hline $\begin{array}{c}\text { Independent } \\
\text { Variables }\end{array}$ & $\begin{array}{c}\text { Dependent } \\
\text { Variables }\end{array}$ & $\begin{array}{c}\text { Adjusted R } \\
\text { Square }\end{array}$ & F & Sig. \\
\hline Green Practice & Sustainability & 0.918 & 1936.663 & 0.000 \\
\hline Green Practice & $\begin{array}{l}\text { Purchase } \\
\text { Intention }\end{array}$ & 0.669 & 276.419 & 0.000 \\
\hline Sustainability & $\begin{array}{l}\text { Purchase } \\
\text { Intention }\end{array}$ & 0.613 & 142.791 & 0.000 \\
\hline
\end{tabular}

\section{Discussion}

The purpose of this study is to explore the generation $\mathrm{Y}^{\prime}$ perception of green practice in foodservice industry, and investigate the impacts of their perceptions on sustainability, and whether it will has an impact on purchase intention.

Through this study, it is empirically verified that the generation $\mathrm{Y}^{\prime}$ perception of green practice in foodservice industry has a positive impact on sustainability. This finding is also supporting the previous studies that indicating younger and better educated members of the public appear to be more concerned about issues of environmental quality and more committed to environmental protection [32]. The most important thing that must be kept in mind is that the positive relationship between the two constructs was arisen from the perception of the generation $\mathrm{Y}$ about green practice in foodservice industry. The right understanding from the foodservice management about consumer's services preferences will lead them in determining types of green practice that are going to be applied, and can be discerned by the consumers, specially by generation Y. Based on previous studies, younger people (ages 35 years or younger) tend to consider using organic foods and reducing the ecological footprint of the restaurant as important for a restaurant [5].

The generation $Y^{\prime}$ perception of green practice in foodservice industry has positive impact of their purchase intention. This finding supports the previous studies that revealed a person's knowledge about an issue significantly influences one's decision making regarding that issue [33]. For example, people's knowledge about green practices and their own use of them will influence their decision to choose a business that also follows green practices. Moreover, numerous studies have shown that knowledge about the environment generally motivates people to behave in an environmentally-responsible manner and choose businesses that do likewise [34, 35]. A strong relationship between consumers' knowledge of green restaurants, environmental concerns, ecological behaviors and intentions to patronize a green restaurant [35]. The environment was the fourth most important issue, preceded by health insurance, living wages and animal welfare. The most recent trend however, is that consumers want to believe they are doing something good while eating out [36]. A number of studies have looked at the impact of demographic factors and how they relate to the perception of green practices and consumer behavior. The majority of respondents in this study were female, although not included in the hypothesis, gender influenced consumer perceptions about purchase intentions to the green restaurants. Women were more likely to report taking part in "green" shopping, but not in recycling or contributing to environmental organizations [32]. Furthermore, women were more likely to express concern about local and statewide pollution and more prepared than men to pay the regulatory, but not the economic, costs of environmental protection.

The sustainability concept has positive impact to purchase intention. This finding support the previous studies that substantial proportion of consumers participating in the researches appeared to be aware of eco-friendly foods and purchase the foods, although they perceived price as a barrier [17]. Consumer trust in a green brand is an important purchase criterion which positively influences their purchase of green products [37]. Eco-labelling or eco-certification informs consumers about the green characteristics of the product and motivates them to purchase green products [38]. These studies have suggested that reliable information should be provided in a simple and user-friendly way through product labels. This might build consumer trust and encourage more sustainable purchases. Above findings suggest that eco labelling might not have any impact on consumer green purchase behavior if they do not trust the information provided.

\section{Limitation and Future Research}

Limitations to this study relates to the number of respondents who are not too many. The limitation also comes from the data that comes from one geographical market, which is Tangerang, Indonesia. Therefore, suggestion for the future research, number of respondents would be more and on various geographical markets might reveal different results. 


\section{CONCLUSION}

In conclusion, the result of this study will extend the knowledge about the role of generation $Y^{\prime}$ perceptions of green practice in foodservice operation that may impacting their perception on sustainability and purchase intention. The knowledge about generation $Y^{\prime}$ perception regarding the green practice can be a managerial tool to determine level of the importance placed on green initiatives. This study will add more reference on the green practice in foodservice operations.

\section{ACKNOWLEDGMENT}

The author wish to thank the Chairperson of Pelita Harapan School of Hospitality and Tourism and The Institute of Research and Community Service for the support in this study. We also thank all respondents for their participation.

\section{REFERENCES}

[1] Hu, H.H., Parsa, H.G. and John, S. (2010). The Dynamics of green restaurant patronage. Cornell Hosp. Q, 51, 344-362.

[2] Iurkevych, O., Gustin, L., Blecher, L. and Reiboldt, W. (2014). College Students' Attitudes, Perceived Consumer Effectiveness and Intention to Dine at a Green Restaurant. International Journal of Science Commerce and Humanities, Vol. No. 2 No. 1, January 2014, pp. 61-73.

[3] Tzschentke, N., Kirk, D. and Lynch, P.A. (2004). Reasons for going green in serviced accommodation establishments. International Journal of Contemporary Hospitality Management, Vol. 16 No. 2, pp. 116-124.

[4] Tzschentke, N.A., Kirk, D. and Lynch, P.A. (2008). Going green: decisional factors in small hospitality operations. International Journal of Hospitality Management, Vol. 27, pp. 126-133.

[5] Schubert, F. (2008). Exploring and predicting consumers' attitudes and behaviors towards green restaurants. Master's Thesis, Graduate School of The Ohio State University, Columbus, OH, USA, 2008.

[6] Pawan, M.T., Langgat, J. and Marzuki, K.M. (2014). Study on Generation Y Dining Out Behavior in Sabah, Malaysia. International Journal of Business and Social Science, Vol. 5 No. 11, Oct 2014, pp. 92101.

[7] PwC (2013), "PwC's NextGen: a global generational study evolving talent strategy to match the new workforce reality", available at: www.pwc.com/en_GX/ gx/hr-management-services/ pdf/pwc-nextgenstudy-2013.pdf (accessed 7 January 2016)

[8] Kim, H., Chang, H., Lee, J.W. and Huh, C. (2011). Exploring gender differences on generation y's attitudes towards green practices in a hotel. 16th Graduate Students Research Conference, Houston, TX, 6-8 January.

[9] Sullivan, P. and Heitmeyer, J. (2008). Looking at Gen Y shopping preferences and intentions: exploring the role of experience and apparel involvement. International Journal of Consumer Studies, Vol. 32 No. 3, pp. 285-295.

[10] Renn, K.A., and Arnold, K.D. (2003). Reconceptualizing research on college peer group culture. The Journal of Higher Education, 74(2), 93110.

[11] Poll, Maritz (2007). "Environmentally friendly retail marketing - all hype or consumer preference?" available at: www.maritz.com/MaritzPoll/2007/Maritz-Poll-Environmentally- Friendly-Retail-Marketing-AllHype-or-Consumer-Preference (accessed 5 January 2016).

[12] Lorenzini, B. (1994). The green restaurant, part II: Systems and service. Restaur. Inst., 104, 119-136.

[13] GRA

Available http://www.dinegreen.com/restaurants/standards.asp (accessed on 8 February 2016).

[14] Chou, C.J., Chen, K.S., and Wang, Y.Y. (2012). Green practices in the restaurant industry from an innovation adoption perspective: Evidence from Taiwan. Int. J. Hosp. Management, 31, 703-711.
[15] Kassinis, G. I., and Soteriou, C. (2003). Greening the Service Profit Chain: The Impact of Environmental Management Practices. Production \& Operations Management, 12(3), 386-402.

[16] Dewald, B., Bruin, B.J. and Jang, Y.J. (2013). US consumer attitudes towards 'green' restaurants. Anatolia - International Journal of Tourism and Hospitality Research, pp. 1-10.

[17] An, J. and Kang, K. (2006). Consumption type of housewives about organic and instant food. The Korean Journal of Food and Nutrition, Vol. 19 No. 3, pp. 28-37.

[18] Lee, Y., Hong, M., Ryu, K., Kim, A. and Ha, S. (2009). A survey of consumer's consumption characteristics of environmental-friendly agricultural products - focused on consumers in discount stores. Journal of Food Hygiene and Safety, Vol. 24 No. 6, pp. 111-123.

[19] Vieregge, M., Scanlon, N., and Huss, J. (2007). Marketing locally grown food products in globally branded restaurants: Do consumers care? Journal of Foodservice Business Research, 10(2), 67-82.

[20] Choi, G. and Parsa, H.G. (2008). Green Practices II. Journal of Foodservice Business Research, Vol. 9 No. 4, pp. 41-63

[21] Boulding, W., Karla, A., Staelin, R., \& Zeithaml, V. A. (1993). A dynamic process model of service quality: From expectation to behavioral intentions. Journal of Marketing Research, 30(1), 7-27.

[22] Soderlund, M., and Ohman, N. (2003). Behavioral intentions in satisfaction research revisited. Journal of Consumer Satisfaction, Dissatisfaction and Complaining Behavior, 16, 53-66.

[23] Reichheld, F. F., and Sasser, E. W. (1990). Zero defections: Quality comes to services. Havard Business Review, 68(5), 105-111.

[24] Chan, K. (1999). Market segmentation of green consumers in Hong Kong. Journal of International Consumer Marketing, Vol. 12 No. 2, pp. 7-24.

[25] Laroche, M., Bergeron, J. and Barbaro-Forleo, G. (2001). Targeting consumers who are willing to pay more for environmentally friendly products. Journal of Consumer Marketing, Vol. 18 No. 6, pp. 503-520.

[26] Mostafa, M.M. (2006), Antecedents of Egyptian consumers' green purchase intentions. Journal of International Consumer Marketing, Vol. 19 No. 2, pp. 97-126.

[27] Dutta, K., Umashankar, V., Choi, G. and Parsa, H.G. (2008). A comparative study of consumers' green practice orientation in India and the United States: a study from the restaurant industry. Journal of Foodservice Business Research, Vol. 11 No. 3, pp. 269-285.

[28] Szuchnicki, A. (2009). Examining the influence of restaurant green practices on consumer return intention. (Master's Thesis, University of Nevada, Las Vegas, Nevada). Retrieved from Dissertations \& Theses: The Humanities and Social Sciences Collection (Publication No. AAT 1474416).

[29] Kim, S., Yoon, J., and Shin, J. (2015). Sustainable business-and-industry foodservice. International Journal of Contemporary Hospitality Management, Vol. 27 Iss 4 pp. 648 - 669

[30] DiPietro, R. B., Cao, Y. and Partlow, C. (2013). Green practices in upscale foodservice operations. International Journal of Contemporary Hospitality Management, Vol. 25 Iss 5 pp. 779 - 796.

[31] Nunnally, J.C. (1978). Psychometric Theory. NY: McGraw-Hill.

[32] Klineberg, S. L., McKeever, M. and Rothenbach, B. (1998). Demographic predictors of environmental concern: It does make a difference how it's measured: Research on the Environment. Social science quarterly 79(4): 734-753.

[33] Kaplan, S. (1991). Beyond rationality: clarity-based decision making, in Garling, T. and Evans, G. (Eds), Environment, Cognition and Action, Oxford University Press, New York, NY, pp. 171-190.

[34] Diamantopoulos, A., Schlegelmilch, B., Sinkovics, R. and Bohlen, G. (2003). Can socio-demographics still play a role in profiling green consumers? A review of the evidence and an empirical investigation. Journal of Business Research, Vol. 56 No. 6, pp. 465-473.

[35] Hsin-Hui H, Parsa HG, Self J. (2010). The dynamics of green restaurant patronage. Cornell Hospitality Quarterly, 51(3), 344-362.

[36] LaVecchia G. (2008). Green: The new gold. Restaurant Hospitality, 92(4), 39-44. 
[37] Rahbar, E. and Wahid, N. A. (2011). Investigation of green marketing tools' effect on consumers' purchase behavior. Business Strategy Series, 12 (2), pp. 73-83.

[38] Young, W., Hwang, K., McDonald, S., and Oates, C. J. (2010). Sustainable consumption: green consumer behaviour when purchasing products. Sustainable Development, 18 (1), pp. 20-31. 